Милош Јелић

Универзитет у Београду

Православни богословски факултет

milosjelic@gmail.com

https://doi.org/10.18485/rit.2021.19.35.3
УДК: 27-46

27-662:3

$271.2-662: 3$

Оригинални научни рад

Датум пријема: 2. 12. 2020.

\title{
„ПОНОС“6 И ОДГОВОРНОСТ: ДРУШТВЕНА АНГАЖОВАНОСТ ПРАВОСЛАВНИХ ХРИШЋАНА У ВРЕМЕНИМА КРИЗЕ ${ }^{1}$
}

\section{Резиме}

Основно йитиање мојеї излайање јестие: Да ли и у којој мери савремени йравославни хришћани вияе своје местио у акииивном учестивовану у ярушиивеном живо-

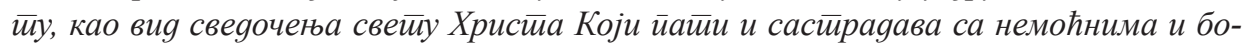

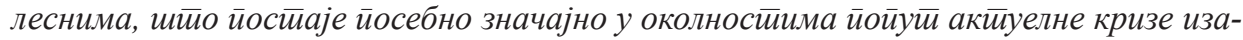
зване йандемијом вируса Ковиg-19? Зайо „,ионосноі" (йоg знацима навоgа, у значе-

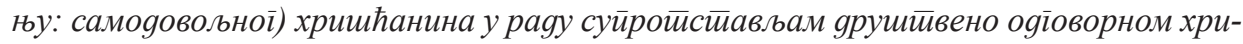

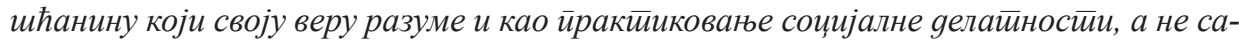

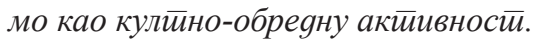

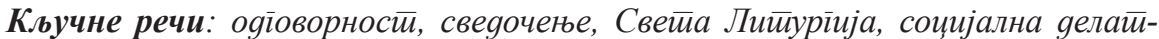
носӣ, Срйска Православна Црква, Руска Православна Црква

\section{Увод}

У уводној речи српском издању Основа социјалне концепције Руске Православне Цркве, за сада једином свеобухватном документу који се бави теоријском обрадом социјалних ставова у православљу, еп. бачки др Иринеј између осталог констатује да се социјална делатност Цркве „одвија као наставак или, тачније, као неотуђиви саставни део њене Евхаристије, њене Литургије, њеног богочовечанског начина постојања, живљења, делања, сведочења, даривања, самоприношења и саможртвовања за живот и спасење света, а у славу Бога Тројединога“"2. Ове речи нашег уваженог владике не бисмо никако могли да доведемо у питање. Ипак, не можемо, а да се истовремено не запитамо каква је практична примена ових речи? Увиђамо ли важност социјалног ангажовања за правилно разумевање самог бића̂ Цркве,

1 Излагање на Националној конференцији са међународним учешћем, „Место стида и поноса у философији, религији и уметности“, 7-8. септембра 2020. године у Београду.

2 Буловић, И., „Уводна реч“ у: Основи социјалне концепције РПЦ, Нови Сад: Беседа, 2011, 7-8. 
имајући пред собом добро познате Христове речи из Матејевог јеванђеља: „Огладнех, и дадосте ми да једем; ожеднех, и напојисте ме; странац бејах, и примисте ме; наг бејах, и оденусте ме; болестан бејах, и посетисте ме; у тамници бејах, и дођосте ми““ (Мт 25, 35-36)?

Епидемија проузрокована корона вирусом званично класификованим као SARS-CoV-2 у Србију је стигла почетком марта ове године. У првом таласу епидемије који се поклопио са великопосном припремом за најважнији хришћански празник - Васкрс, код многих верника је постојала дилема да ли похађати богослужења или не, с обзиром на здравствене непознанице које су пратиле почетну фазу ширења вируса. Са друге стране, имали смо и гласове који су по сваку цену заговарали одлажење у храмове, иако је према у том тренутку расположивим информацијама такво понашање потенцијално било веома ризично. ${ }^{3}$ Ни код једних ни код других, међутим, јавно се није могло чути размишљање о организовању било каквог вида прикупљања помоћи, или, пак, личног учествовања у акцијама исказивања солидарности са најугроженијим слојевима становништва, међу којима су били и они старији од 65 година којима је у то време у потпуности била ускраћена слобода кретања. О бризи за оне које је болест на разне начине директно погодила, тек није било речи ${ }^{4}$. Један од узрока оваквог расположења свакако би могао да лежи у још увек у недовољној мери развијеној организационој структури милосрдног деловања на нивоу СПЦ ${ }^{5}$, што је за последицу имало немогућност да и они који су били спремни да помогну, нису то могли да учине без адекватне организационе подршке. Оно што је ипак, по моме мишљењу, у највећој мери допринело неадекватном одговору верујућег народа на изненадну кризу, поред „паралишућег страха““6 - био је пре свега недоста-

3 Једна од ударних вести у медијима била је и она о великом броју заражених у познатом центру духовности, Кијево-печерској лаври. („Један од најважнијих манастира у Украјини жариште короне“, прегледано 2.9.2020. године на: https://sptnkne.ws/CbRj).

4 Било је и позитивних примера, попут акције Епархије диселдорфске и немачке у којој су прикупљена новчана средства у износу од 23.000 евра, потом усмерена на куповину опреме болницама погођеним епидемијом Ковид-19. („Помоћ болницама у Београду, Призрену и Бања Луци“, прегледано 2.9.2020. године на: https://www.covekoljublje.org/rs/ vesti/2/2020/07/10/pomoc-bolnicama-u-beogradu-prizrenu-i-banja-luci.html)

5 Осим добротворне фондације „Човекољубље“ (https://www.covekoljublje.org/rs/) не постоји организација која би имала шири обим деловања на нивоу СПЦ. Од епархијских организација издваја се Верско добротворно старатељство Архиепископије београдско-карловачке (ВДС) (https://starateljstvo.rs/).

6 „Страх од корона вируса нас паралише. Безбројни виновници смрти вребају у сваком делићу секунде. Корона вирус нас држи у страху, јер га не познајемо. Изненадио нас је и немамо начина да се одбранимо - немамо ни лек, ни вакцину. Статистичка вероватноћа да ћемо се заразити, доведена до врхунца, рађа панику - да ће нас задесити мучна смрт у бол- 
так јасне свести о поменутој вези богослужбеног живота и активног практиковања харитативне делатности. (Не)свесни своје личне и друштвене одговорности, рекао бих да се нисмо у кључним тренуцима снашли на испиту човечности, иако, као што сам то навео, постоје можда и оправдани разлози за то (ако постоје).

\section{Хришћанство и криза}

Владета Јеротић нас је често подсећао да криза не мора увек да значи нешто лоше, напротив. За хришћане је криза добра прилика да преиспитају своје погрешне ставове и уверења, свој однос према себи, према другом човеку, према свету који их окружује. ${ }^{7}$ Штавише, историја нам показује да су хришћани у нарочито кризним временима, давали свој максимум кроз спремност на жртву зарад ближњег. У временима смртоносних епидемија, које - иако то зачуђујуће звучи за нас, људе 21. века, углавном навикле на комфоран и лагодан живот - и нису биле толика реткост ни пре ове актуелне, хришћани су полагали своје животе из несебичне љубави према људима који су у тим епидемијама страдали, прихватајући на себе њихова страдања, као што нам о томе сведочи Свети Дионисије Александријски:

„Многи од наше браће, из превелике љубави, не марећи за свој живот, брину се један за другог, посећују болеснике, дворе их непрестано, лече их у Христу; они су добровољно умрли заједно са њима узимајући на себе њихова страдања, испирајући им ране предано. Многи од оних који су се тако трудили око болних и повратили им здравље, сами су умрли... И ова врста смрти из побожности и чврсте вере ни по чему није нижа од мучеништва. Они су рукама својим узимали тела светих и држали их на коленима, затварали им очи и уста, носили их на леђима као децу, намештали их, служили им, измивали их и облачили““8.

ничком хаосу панике.“ (Јанарас, Х., „Без-смислен живот и вирус“, прегледано 2.9.2020. на: https://teologija.net/be-smislen-zivot-i-virus/).

7 Када боље размислимо, за хришћане је свако време - време кризе (суда), јер се сви наши поступци непрекидно проверавају и вреднују у односу на Христа Који је и дошао да суди свету. УП. Јн. 12, 31.

8 ЖИТИЈЕ СВЕТОГ СВЕШТЕНОМУЧЕНИКА ДИОНИСИЈА, епископа Александријског, прегледано 2.9.2020. на: https://svetosavlje.org/zitija-svetih-11/6/ 
Није редак случај у људској историји да се природне и друштвене катастрофе преводе и у кризе вере ${ }^{9}$, вели Родни Штарк (Rodney Stark) у својој књизи Успон хришћанства (The rise of Christianity). У том смислу, он као пресудна два догађаја за масовније ширење хришћанства на уштрб паганске религије у Римском царству, види две смртоносне епидемије које су задесиле римско друштво у другој половини другог и половином трећег века. Реч је, најпре, о епидемији великих богиња која је задесила Римско царство 165. године у време владавине Марка Аурелија, када је за петнаест година трајања епидемије према неким проценама између трећине и четвртине укупног становништва Царства умрло од последицаิ заразе, укључујући и са̂мог Марка Аурелија. Друга епидемија, овога пута малих богиња, појавила се 251. године, а на њеном врхунцу је само у граду Риму умирало пет хиљада људи дневно! Број становника града Александрије у којој је Свети Дионисије столовао, смањио се у време трајања епидемије чак за две трећине. ${ }^{10}$ Наравно да су у обема епидемијама умирали и хришћани и пагани, али како нам Штарк сугерише на основу доступних му извора, у много већој мери пагани. За разлику од хришћана, који, као што то читамо код Дионисија, нису штедели себе бринући се о болеснима, пагани су се повлачили у оно што бисмо назвали данас популарним термином - самоизолација. Заправо, они су бежали од заражених, чак и од својих најмилијих, сматрајући да ће на тај начин моћи да избегну болест. ${ }^{11}$ Кључна разлика између хришћана и пагана у тим временима била је у делатној љубави, по угледу на Христа. Јер, оно што је хришћанство као новину донело у грчко-римски свет била је чврста повезаност између веровања и деловања. Хришћанин не може да удовољи Богу уколико не покаже љубав према ближњем, о чему постоје бројна сведочанства још у Старом завету ${ }^{12}$. Пророци опомињу све оне који чине не-

9 Stark, R., The rise of Christianity: How the obscure, marginal Jesus movement became the dominant religious force in the Western world in a few centuries. San Francisco, Calif: Harper San Francisco, 1997, 77.

10 Исто.

11 Stark, R., нав. gело, 83. Остаје записано да је чувени антички лекар Гален, међу првима побегао из Рима када је избила епидемија великих богиња!

12 „Ко чини криво убогоме, срамоти створитеља његова; а поштује га ко је милостив сиромаху“ (Прич. 14, 31), каже се у Причама Соломоновим. Зато је у временима када је изостајала брига световних и духовних вођа, као и свих имућнијих чланова заједнице за оне потребите у Израиљу, Бог опомињао преко својих пророка, не желећи да прими жртве иза којих није стајала друштвена праведност. Постоје чак мишљења да је читав пророчки покрет у Старом завету изникао управо из потребе да се обрати пажња на маргинализоване друштвене групе: „Пророци су били заговорници идеје да су сви једнаки пред Богом, јер је Бог створио човека 'по лику и подобију' своме. Угрожавање тих права било је неприхватљиво и неспоји- 
правду нижим слојевима друштва, а Бог не жели да прими жртвоприношења оних који су се огрешили о сиромахе, удовице и остале ${ }^{13}$. Једнако важно, хришћани су за разлику од припадника паганских култова осим спремности да непосредно пруже помоћ свакоме без изузетка, људима нудили и смисао живљења, али и смисао страдања и патње! ${ }^{14}$. Колико је таква жртва узвишена, видимо по томе што је Дионисије у своме опису изједначава са мучеништвом! Велики број хришћана, међу њима и свештеника и ђакона, изгубио је тада свој живот бринући за оболеле. Добро знамо да је према православном учењу добровољно мучеништво темељ хришћанске вере, односно да је Црква изграђена на крви мученика који су непоколебиво сведочили своју веру у временима прогона, и то не само у прва три века хришћанске историје. Дионисије једнако важним сматра и полагање живота за ближње кроз непосредно састрадавање и патњу са најугроженијима, што све не би било могуће без чврсте вере у васкрсење. Хришћани су и тада, као и данас, живели непоколебивом вером и убеђењем да се живот не завршава са крајем земаљског постојања, па им је отуда било неупоредиво лакше да се посвете бризи за угрожене, али и да пруже утеху онима чији су највољенији страдали.

\section{Богослужење и служење}

Оно што Штарк у својој књизи истиче, а што је и за нас важно у контексту теме о којој говоримо, јесте закључак да није проблем паганског света био у томе што они нису знали за милосрђе, већ што то милосрђе није било утемељено на служењу боговима. ${ }^{15}$ Етичке импликације жртвоприношења за паганско богослужење нису биле важне - пагански богови нису кажњавали етичке преступе, јер пред своје следбенике нису постављали никакве етичке захтеве. ${ }^{16}$

Са друге стране, библијска, а можемо слободно да кажемо и светоотачка традиција Цркве указује на чврсту повезаност између богослужења и во са вером у Бога. Из тог амбијента изниче пророчки покрет“ (Кубат Р., „Пророци - глас Божији у Израилу“, приступљено 1.5.2020. на: https://teologija.net/prorociglas-boziji-u-izrailu/).

13 УП. Ам. 5, 11-12, 21-23; Ис. 1, 11, 13-14, 16-17 и друга слична места.

14 Или, како то Штарк дефинише: „У времену када су све остале вере доведене у питање, хришћанство је понудило објашњење и утеху“. (Stark, R., нав. gело, 82)

15 Stark, R., нав. яело, 88.

16 Уосталом, богови грчко-римског света и нису представљали некакав етички идеал, па следствено, ни од оних који су им одавали поштовање, у етичком смислу није могло да се очекује ништа боље. 
служења другима ${ }^{17}$. С тим у вези, у многим новозаветним текстовима и код раних Отаца, употреба термина ,литургија“ односи се на ранохришћанско богослужење, једнако као и на обавезу да се задовоље материјалне и друге потребе заједнице. ${ }^{18}$ Проблем настаје онда када се ове две сфере хришћанског живота одвоје, па уместо да са-постоје, почињу да егзистирају независно једна од друге. Та раздељеност показала се у свој својој оштрини управо у наше дане, по избијању актуелне епидемије корона вируса.

По проглашењу ванредног стања у земљи, једна од мера Владе Републике Србије била је и ограничење кретања за сва лица у одређеним временским интервалима. Ова мера је посебно погодила верујуће људе, јер се поменута забрана неколико пута односила и на дане викенда, па је самим тим представљала и немогућност да се одлази на Свету Литургију. Иако је било и оних који су указивали на чињеницу да се ограничење кретања односи на припаднике свих религија, јер су сви подједнако њоме били погођени у обављању својих верских потреба, а не само на хришћане ${ }^{19}$, могла су да се чују и супротна мишљења. Отежавајућа околност била је што поменуте мере долазе у време када су се хришћани припремали за прославу Васкрса, а испоставиће се да и свој најрадоснији празник нису могли да прославе у својим храмовима. Управо је та чињеница довела до својеврсног бунта међу православнима и изазвала бројне контроверзе. Могли су тада да се чују позиви да, без обзира на наметнута ограничења треба доћи у храм, јер је то „одлична прилика“ за исповедништво, уколико би вас, на пример, због тога полиција приводила, а лично сам могао да чујем од појединих верника мишљење да они који би се у датим околностима заразили у цркви и од последица заразе евентуално умрли - заправо на тај начин страдали за Христа! 20

Све ово наводим, не да бих критиковао (не дао Бог!), већ да бих указао на драстичну разлику између понашања хришћана у поменутим епидемија-

17 УП. Clapsis E., "The Eucharist as Missionary Event in a Suffering World”, y: Clapsis, E., Orthodoxy in Conversation: Orthodox Ecumenical Engagements, Geneva: WCC Publications, 2000,193 . Изостанак ове везе неизбежно води ка наглашавању култа, што даље води ка својеврсном „литургијском ескапизму“ пред изазовима историје, сматра Клапсис (нав. gело, 192).

18 УП. Holman, Susan R., The Hungry Are Dying: Beggars and Bishops in Roman Cappadocia, Oxford: Oxford University Press, 2001, 48.

19 Тупањанин, Д., „На сцени је борба против пандемије, не против хришћанства“, прегледано 5.9.2020. на: https://teologija.net/na-sceni-je-borba-protiv-pandemije-ne-protivhriscanstva/

20 У анализу теоријаิ које „мере“ снагу нечије вере, а према којима људи ,јаке“ вере не треба да се боје заразе и да треба слободно да долазе у храм, а да они који су „слаби“ у вери треба да остану (да ли тако „неверујући“ и „бескорисни“?) код својих кућа, овом приликом не бих ни могао, а ни желео да улазим. Подсетићу само на речи Светог апостола Павла: „Дужни смо пак ми јаки слабости слабих носити, и не себи угађати.“ (Рим 15,1$)$ 
ма рано-хришћанског друштва и нашег данашњег. Јер, видели смо то, Свети Дионисије говори о онима који страдају у епидемији док помажу болеснима (притом не ограничавајући своје милосрђе искључиво на припаднике своје вере!) као о мученицима, што они свакако и јесу. Са друге стране, имамо наше, да га тако назовем, савремено схватање мучеништва у време епидемије, које понекад подразумева одлазак у храм по сваку цену, нажалост чак и по цену угрожавања туђих живота! Једно, дакле, рекао бих, потпуно аутистично схватање вере у којем је JА, а не ТИ на првом месту, за разлику од несебичног јеванђељског себедавања.

\section{Нада}

Ипак, да нада постоји сведочи пример Руске Православне Цркве. Као прва Помесна Црква која је у 21. веку систематски почела да се бави социјалном делатношћу, РПЦ је и у случају актуелне пандемије предњачила на пољу бриге за посебно угрожене слојеве становништва. Према извештају ${ }^{21}$ митрополита воскресенског Дионисија 22 , председника Радне групе за координацију активности црквених институција у условима ширења заразе коронавирусом, у марту је у оквиру Синодског одељења за добротворну делатност и службе „Милосрђе““ организован московски штаб за црквену помоћ. У периоду од 20. марта до 17. августа 2020. године, само је у Москви упућено скоро 20.000 телефонских захтева за помоћ преко тзв. „вруће линије“. По угледу на Москву, отврене су до сада укупно 102 такве линије у осталим епархијама РПЦ ${ }^{23}$. Такође, у Москви је организована група ${ }^{24}$ од 18 специјално обучених свештеника и њихових помоћника за посету оболелима од коронавируса која је у периоду од 2. априла до 17. августа обавила 498 посета. Слично је учињено и у многим епархијама РПЦ. Према речима митрополита Дионисија, у време епидемије се повећао број добровољаца - у ра-

21 „Доклад председателя Рабочей группы по координации деятельности церковных учреждений в условиях распространения коронавирусной инфекции на заседании Священного Синода 25 августа 2020 года“, прегледано 2.9.2020. године на: http://www.patriarchia.ru/ $\mathrm{db} / \mathrm{text} / 5681862 . \mathrm{html}$.

22 Занимљива је подударност у именима епископа александријског и митрополита воскресенског.

23 Списак линија доступан на адреси: http://www.diaconia.ru/koronavirus-goryachielinii-pomoshhi.

24 „Священники и их помощники готовы оказать помощь людям с коронавирусом и всем тем, кто находится на изоляции“, прегледано 2.9.2020. на: http://www.diaconia. ru/svyashhenniki-i-ikh-pomoshhniki-gotovy-okazat-pomoshh-lyudyam-s-koronavirusom-i-vsemtem-kto-nakhoditsya-na-izolyacii 
ду више од 100 волонтерских служби учествовало је више од 7.000 добровољаца ${ }^{25}$. У неким епархијама су и сами архијереји узимали активног учешћа у достављању помоћи угроженима. Занимљиво је да је за то време патријарх московски и све Русије недвосмислено позивао вернике да не долазе у храмове због потенцијалне опасности од заразе. ${ }^{26}$ Као последица његовог позива, на највећи хришћански празник - Васкрс, у храму Христа Спаситеља у Москви били су само они који су активно учествовали у служењу Свете Литургије (клир, појци), иако на снази није било никакво ограничење кретања, као код нас.

Шта нам овај пример показује? Показује нам да су црквени лидери и верни народ Руске Православне Цркве у ситуацији када се читав свет суочио са кризом још увек несагледивих размера, понели крајње одговорно, не сводећи црквени живот само и искључиво на храмовно богослужење ${ }^{27}$, већ и на служење ближњем, као својеврсну службу Богу ${ }^{28}$. Тиме су дали добар пример и осталим православним хришћанима како делатна вера треба да изгледа. Није, дакле, овде реч о дилеми „или/или“ - или Литургија (богослужење) или социјална делатност - већ о свести да су и Литургија и активна помоћ ближњем подједнако важни. ${ }^{29}$ Постоји нада да ћемо и ми у будућно-

25 „Церковь развернула более 100 добровольческих служб: помогают почти 7 тысяч волонтеров“", прегледано 2.9.2020. године на: http://www.diaconia.ru/cerkov-razvernula-bolee100-dobrovolcheskikh-sluzhb-pomogayut-pochti-7-tysyach-volonterov

26 „Патриаршая проповедь в Неделю 4-ю Великого поста после Литургии в Храме Христа Спасителя“, прегледано 2.9.2020. на: http://www.patriarchia.ru/db/text/5613859.html.

27 Што у одређеном смислу илуструју и речи Патријарха Кирила: „Пример Марије Египћанке сведочи о томе да се и без посете храму може спасити. Уосталом, нисам вам дао неки вештачки пример, већ пример светитељке чији спомен обележавамо ове недеље. Светитељке која је напустила све храмове и манастире и повукла се у пустињу... Далеко од манастира и храмова, у самоћи, у далекој пустињи, света Марија је спасила душу и дала снагу физичком телу да у невероватно тешким условима живи тачно онолико година колико је Господ дозволио.“ (нав.извор). Наравно да треба бити обазрив и не схватати ове речи изван контекста у којем су изречене, а то је већ поменута ситуација у којој патријарх позива вернике да се уздрже од долажења у храмове у току пандемије, сугеришући им да и у својим домовима могу да се молитвено владају попут Свете Марије, која је, треба и то рећи, свој земаљски живот завршила причешћем Светим тајнама Христовим. Хришћанство изискује заједницу. Нико не може да се спасава са̂м за себе, односно без других, било да је у свету, општежитељном манастиру, или у индивидуалном подвигу по келијама и испосницама!

28 „И одговарајући Цар, рећи ће им: Заиста вам кажем: кад учинисте једноме од ове моје најмање браће, мени учинисте.“(Мт. 25, 40).

29 У том смислу Растко Јовић пише: „Као što je smrt stvarna i bolna, tako bi se upravo i Crkva trebala boriti za predokus istinitoga Kraljevstva Božjega u ovom svijetu, u svim njegovim aspektima. Borba za taj predokus izgaranje je s problemima, s konkretnim izazovima, ne dopuštajući da se ikona Kraljevstva Božjega svede samo na liturgiju - nego da ima istinite društvene dimenzije“ (Jović, R., „Strah milosrđa“, u: O božjem milosrđu, zbornik radova s Međunarodnoga znanstvenog simpozija o milosrđu održanog 22. travnja 2016. godine na Katoličkom bogoslovnom fakultetu u Đakovu Sveučilišta Josipa Jurja Strossmayera u Osijeku, Đakovo, 2016, 163-175, 166) 
сти почети да у већој мери следимо њихов пример када је друштвена ангажованост у питању. Хвала вам на пажњи.

\section{Литература}

Clapsis E., "The Eucharist as Missionary Event in a Suffering World". In: Clapsis, E., Orthodoxy in Conversation: Orthodox Ecumenical Engagements, Geneva: WCC Publications, 2000.

Holman, Susan R., The Hungry Are Dying: Beggars and Bishops in Roman Cappadocia, Oxford: Oxford University Press, 2001.

Jović, R., „Strah milosrđa“. U: O božjem milosrđu, zbornik radova s Međunarodnoga znanstvenog simpozija o milosrđu održanog 22. travnja 2016. godine na Katoličkom bogoslovnom fakultetu u Đakovu Sveučilišta Josipa Jurja Strossmayera u Osijeku, Đakovo, 2016, 163-175.

Stark, R., The rise of Christianity: How the obscure, marginal Jesus movement became the dominant religious force in the Western world in a few centuries. San Francisco, Calif: Harper San Francisco, 1997.

Тупањанин, Д., „На сцени је борба против пандемије, не против хришћанства“, прегледано 5.9.2020. на: https://teologija.net/na-sceni-je-borba-protiv-pandemije-ne-protiv-hriscanstva/.

Буловић, И., „Уводна реч““. У: Основи социјалне концепције РПЦ, Нови Сад: Беседа, 2011.

Житије светог свештеномученика Дионисија, епископа Александријског, прегледано 2.9.2020. на: https://svetosavlje.org/zitija-svetih-11/6/

Јанарас, Х., „Без-смислен живот и вирус“, прегледано 2.9.2020. на: https://teologija. net/be-smislen-zivot-i-virus/

Кубат Р., „Пророци - глас Божији у Израилу“, приступљено 1.5.2020. на: https://teologija.net/proroci-glas-boziji-u-izrailu/

\section{Иниеерней извори}

„Доклад председателя Рабочей группы по координации деятельности церковных учреждений в условиях распространения коронавирусной инфекции на заседании Священного Синода 25 августа 2020 года“, прегледано 2.9.2020. године на: http://www.patriarchia.ru/db/text/5681862.html

„Један од најважнијих манастира у Украјини жариште короне“, прегледано 2.9.2020. године на: https://sptnkne.ws/CbRj

„Патриаршая проповедь в Неделю 4-ю Великого поста после Литургии в Храме Христа Спасителя““, прегледано 2.9.2020. на: http://www.patriarchia.ru/db/ text/5613859.html

„Помоћ болницама у Београду, Призрену и Бања Луци“, прегледано 2.9.2020. године на: https://www.covekoljublje.org/rs/vesti/2/2020/07/10/pomoc-bolnicama-u-beogradu-prizrenu-i-banja-luci.html

„Священники и их помощники готовы оказать помощь людям с коронавирусом и всем тем, кто находится на изоляции“, прегледано 2.9.2020. на: http://www.diaco- 
nia.ru/svyashhenniki-i-ikh-pomoshhniki-gotovy-okazat-pomoshh-lyudyam-s-koronavirusom-i-vsem-tem-kto-nakhoditsya-na-izolyacii

„Церковь развернула более 100 добровольческих служб: помогают почти 7 тысяч волонтеров“", прегледано 2.9.2020. године на: http://www.diaconia.ru/cerkov-razvernula-bolee-100-dobrovolcheskikh-sluzhb-pomogayut-pochti-7-tysyach-volonterov

https://www.covekoljublje.org/rs/

https://starateljstvo.rs/

\title{
Miloš Jelić
}

University of Belgrade

Faculty of Orthodox Theology

milosjelic@gmail.com

\section{"PRIDE" AND RESPONSIBILITY: SOCIAL ENGAGEMENT OF ORTHODOX CHRISTIANS IN TIMES OF CRISIS}

\begin{abstract}
Summary
The basic question of my paper is: Do modern Orthodox Christians see their place in active participation in social life, as a form of witnessing to the world of Christ who suffers with the infirm and the sick, which becomes especially important in circumstances such as the current Covid-19 pandemic? That is why I oppose a "proud" (with quotation marks, meaning: self-sufficient) Christian to a socially responsible Christian who understands his faith as a social praxis, not only as a cult-oriented activity.
\end{abstract}

Keywords: responsibility, witnessing, Holy Liturgy, social activity, Serbian Orthodox Church, Russian Orthodox Church 